臨床薬理のこころ $(\mathbf{1})$

\title{
臨床試験と倫理
}

\begin{abstract}
臨床研究に関する倫理規定は古くは Hippocrates に始まりその数は多いが，近年のもの は大体 1947 年の Nürnberg 判決を下敷としていると考えていい. アメリカの Public Health Service, American Medical Association, イギリスの Medical Research Council, フランスの Académie Nationale de Médecine のものなどがこれに属する. World Medical Association では 1948 年の Geneva 宣言, 1949 年の国際医師倫理規定のあとを受 けて，1964 年 6 月 Helsinki でひらかれた第 18 回総会で次の宣言を採択した.
\end{abstract}

砂 原 茂 一*

\section{Helsinki 宣言}

第 18 回世界医師会, 1964 年, Helsinki

医師の使命は人々の健康を守ることにある．医 師の知識と良心はこの使命遂行のためにささげら れる。

世界医師会 (World Medical Association) の Geneva 宣言は医師に“私の患者の 健康は私の第 一の関心事となるであろう”ということばに従う よう要請している。また国際医師倫理規定は“人 間の身体的，精神的抵抗を弱めるようないかなる 行為や助言も，その人の利益になる場合にのみ許 される”と宣言している.

科学知識の進歩をはかり㥗んでいる人間を助け るためには，研究室内の実験の結果を人間に応用 することはどうしても必要であるとの理由から， 世界医師会は次の勧告を臨床試験を行なら医師の 手引きとして提示した。 ここに起草された基準は 全世界の医師に対する一つの指針でしかないこと を強調しなくてはならない，医師は自分自身の国 の法律に基づく刑事上，民事上，道義上の責任を まぬがれることはできないのである。

臨床試験の領域では，患者のための治療を本来 の目的とする臨床研究と, 本来の目的が研究対象

\footnotetext{
* 国立療養所東京病院
}

となつた人に対して行われる治療的意味をもたな い純科学的な臨床研究との間に基本的な区別を認 めなくてはならない.

\section{I. 基本原則}

1. 臨床研究は医学上の研究を正当化する倫理 的，科学的原則に合致しなくてはならず，また実 験室内および動物での実験とかその他科学的に確 立された事実に基づいて行なわれたものでなくて はならない。

2. 臨床研究は科学的有資格者によつて，資格 ある医師の監督のもとに行なわれなくてはならな い.

3. 目的の重要性が被験者のこうむるかも知れ ない贷険性につりあつたものでないかぎり，臨床 試験は正当化され得ない。

4. すべての臨床試験計画に先だつて，被験者 またはその他の人々にもたらされる利益と比較し て，それにつきまとう危険を慎重に評価しなくて はならない。

5. 薬物や実験手技によつて被験者の人格が影 響を受けやすいような臨床試験を行なう場合，医 師はとくに慎重な注意を払わなければならない．

\section{II. 専門的治療と結びついた臨床試験}

1. 患者を治療するに際して，医師は自分の判 
断で生命を救い，健康を回復し，苦痛を軽減でき るなどの希望があると考えたなら，新しい治療手 段を用いることに自由でなくてはならない，患者 の心理状態を十分慮しながら，医師はできるだけ 十分な説明をしたうえで，患者の自由意志による 同意を得ておくべきである. 法的に無資格者の場 合は，同意は後見人から求めるべきで，身体的に 不可能な人の場合は, 患者の代りに後見人の承諾 を得なければならない。

2. 医師は臨床試験を新しい医学知識を得る目 標として，専門的治療と結び付けることができる が，それは臨床研究が患者にとつて治療的価值が あると正しく判断された範囲内に限られるべきで ある。

\section{III. 治療と無関係な臨床試験}

1. 臨床試験が人間について:純科学的な目的で 行なわれる場合, 医師には臨床試験の行なわれる 人の生命と健康の保護者となる義務がある.

2. 臨床試験の本質, 目的ならびに危険性を医 師は被験者に説明しなければならない。
3 a. 人間に行なわれる臨床試験は, 説明された らえでの自由な同意なしには着手してはならな い. 法的に責任能力がない場合は後見人の同意を 得なければならない。

$3 \mathrm{~b}$. 臨床試験の被験者は 選択の 能力が十分に 発揮できるだけの精神的，身体的ならびに法的の 状態にあることが必要である.

$3 \mathrm{c}$. 原則として同意は文書として示さるべき である.しかし臨床試験の責任はつねに研究者の 側にある．同意を与えたからといつてその責任が 被験者にふりかかつてくるようなことはない．

$4 \mathrm{a}$. これはとくに被験者が研究者をたよらね ばならぬ関係にある場合そうであるが，それぞれ の人が自分本来の完全な状態をまもる権利を研究 者は尊重しなければならない。

$4 \mathrm{~b}$. 被験者あるいはその後見人は臨床試験の 途中でその試験を続ける許可をいつでも自由に取 り消せなくてはならない. 研究者もしくは研究チ ームは，自らの判断で試験を続けるとその人に有 害ではないかと考えたら, 研究を中止しなければ ならない。 